\section{The determinants of securities trading activity: evidence from four European equity markets}

Determinants of securities trading activity

\author{
Banking and Finance Department, University of Malta, Msida, Malta, and \\ Francelle Galea \\ FIMBank plc, St Julian's, Malta
}

Silvio John Camilleri
Received 26 February 2019
Revised 14 March 2019
9 April 2019
Accepted 15 April 2019

\begin{abstract}
Purpose - The purpose of this paper is to obtain new empirical evidence about the connections between equity trading activity and five possible liquidity determinants: market capitalisation, dividend yield, earnings yield, company growth and the distinction between recently listed firms as opposed to more established ones.

Design/methodology/approach - The authors use a sample of 172 stocks from four European markets and estimate models using the entire sample data and different sub-samples to check the relative importance of the above determinants. The authors also conduct a factor analysis to re-classify the variables into a more succinct framework.

Findings - The evidence suggests that market capitalisation is the most important trading activity determinant, and the number of years listed ranks thereafter.

Research limitations/implications - The positive relation between trading activity and market capitalisation is in line with prior literature, while the findings relating to the other determinants offer further empirical evidence which is a worthy addition in view of the contradictory results in prior research.

Practical implications - This study is of relevance to practitioners who would like to understand the cross-sectional variation in stock liquidity at a more detailed level.

Originality/value - The originality of the paper rests on two important grounds: the authors focus on trading turnover rather than on other liquidity proxies, since the former is accepted as an important determinant of the liquidity-generation process, and the authors adopt a rigorous approach towards checking the robustness of the results by considering various sub-sample configurations.
\end{abstract}

Keywords Dividend yield, European equity markets, Factor analysis, Liquidity, Liquidity determinants, Market capitalisation, Newly established firms, Securities markets, Trading activity

Paper type Research paper

\section{Introduction}

The impacts of distinct market features on stock trading constitute an important aspect of finance research, particularly in view of the increased emphasis on market microstructure issues. Trading volumes and liquidity are of central importance as detailed below, and these two features are closely inter-related as shown in the studies of Jones (2001), Amihud (2002), Foucault et al. (2005) and Rosu (2009). Whilst the terms liquidity and trading volumes convey close similarity, one should note that prior studies yielded mixed evidence regarding the link between the two variables. For instance, Lee et al. (1993) documented a negative relationship in the context of the New York Stock Exchange, whereas Khang and King (2010) reported a positive relationship in case of the US Treasury note market. In addition,

\section{JEL Classification - G10, G12, G15}

(C) Silvio John Camilleri and Francelle Galea. Published in Journal of Capital Markets Studies. Published by Emerald Publishing Limited. This article is published under the Creative Commons Attribution (CC BY 4.0) licence. Anyone may reproduce, distribute, translate and create derivative works of this article (for both commercial and non-commercial purposes), subject to full attribution to the original publication and authors. The full terms of this licence may be seen at http://creative commons.org/licences/by/4.0/legalcode

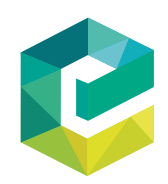

Journal of Capital Markets Studies Vol. 3 No. 1,2019 
JCMS

3,1

48

the transaction cost aspect relating to liquidity is not readily captured by yardsticks such as trading turnover or number of shares transacted.

One main factor which explains the interest in trading volumes is that it constitutes an important determinant of liquidity (Brennan and Subrahmanyam, 1996). The latter attracted the attention of academics, partly because finance theory typically assumes that securities may be transacted without incurring adverse liquidity-related price impacts. Traders are interested in the topic given that illiquidity increases transaction costs and may even compromise strategy feasibility.

The impact of liquidity on stock prices is of central pertinence in finance literature, and studies suggest that liquidity influences stock prices - at least in the short term. Liquidity shocks may be expected to exert a considerable impact on asset prices (Pastor and Stambaugh, 2003; Bekaert et al., 2007), even in the absence of any changes in fundamental values (Chordia et al., 2003). Reduced liquidity may result in non-synchronous trading effects which give the impression that prices react to news with a delay (Day and Wang, 2002; Camilleri and Green, 2014). Conversely, liquid markets are inherently more efficient since their ability to accommodate order flow results in lower price impact of transactions which deviates trading prices from the inherent value of securities (Chordia et al., 2005). Amihud and Mendelson (1986) suggest that firms may reduce their cost of capital by improving the liquidity of their shares.

One important element which illustrates the distinction between trading activity and liquidity is the diversity of traders' opinions, as elaborated by Harris and Raviv (1993) and Tambakis (2006). Diversity of opinion is more likely to materialise in two-sided order flow, which is essential for traders to find counterparties. Conversely, when markets panic and order flow is mainly on the sell side, liquidity is likely to be low despite the typical increase in trading activity witnessed during market crises.

In view of such insights, the liquidity-generation process and its influencers are vital in understanding the dynamics of securities markets with the aim of facilitating trading activity. The latter may be expected to materialise in noteworthy advantages such as the ability to trade assets promptly with minimum price impact and the fostering of investment and capital inflows.

In this paper we focus on the connections between equity trading activity and five business-specific characteristics: market capitalisation (CAP), dividend yield (DY), earnings yield (EY), growth rate (GR) and the distinction between established firms and those which were listed relatively recently (YRS). These linkages are assessed through a sample of equities assembled from four European markets: the London Stock Exchange, the Madrid Stock Exchange, the Malta Stock Exchange and the Vienna Stock Exchange. Our data set therefore comprises a mixture of securities emanating from both established and novel trading venues. In particular we sample 50 random stocks from each exchange, with the exception of the Malta Stock Exchange from where we take the whole population of traded equities amounting to 22.

We estimate different models to inquire which of the former variables are significantly related to the cross-sectional variation in trading turnover of the sampled stocks. We then consider sub-samples as a form of robustness check, and also re-organise the variables into factors (using factor analysis) to achieve a more succinct insight regarding trading activity influencers.

The layout of this paper is as follows. We review the relevant literature in Section 2, while Section 3 offers details about the methodology. In Section 4 we describe the data set and the empirical results are presented in the subsequent section. Section 6 concludes.

\section{Literature review}

\subsection{Trading activity and liquidity: connections and related proxies}

The important connections between trading activity and liquidity were analysed since as early as Demsetz (1968) and Tinic (1972) who proposed that trading volume constitutes a 
main determinant of liquidity, together with other factors such as firm size and volatility. As explained above, higher trading activity does not automatically imply additional liquidity and therefore the concepts are not perfect substitutes. Having said this, in view of the important connections between the two variables, in this literature review we include those studies where the main focus lies on trading activity as well as liquidity.

Amihud and Mendelson (1986) defined the concept of liquidity as the ease with which an asset is traded whilst offering the lowest possible price concession. In this way the tighter the difference between the trading price and the inherent value of an asset, the higher the liquidity. This notion may be approximated by the bid-ask spread, where a higher spread implies a higher price concession being offered to attract a trading counterparty. Studies such as Amihud and Mendelson (1991), Eleswarapu (1997) and Elyasiani et al. (2000) suggested that traders demand higher returns to compensate for lower liquidity. Jeong et al. (2018) reported that since investors are risk averse, a decrease in liquidity may have wider impacts on security prices as compared to a commensurate increase in liquidity.

Given that liquidity is a multi-faceted concept as discussed by Kyle (1985), a range of liquidity proxies was proposed in academic literature. For instance, Brennan and Subrahmanyam (1996) confirmed that trading volume is a determinant of liquidity, and this yardstick was used as a liquidity proxy in various studies such as Chordia et al. (2001). Lo and Wang (2000) contended that share turnover is the most suited proxy of trading activity.

The bid-ask spread is a commonly used measure of liquidity, with Amihud and Mendelson (1986) being one of the first studies that proposed the spread as a liquidity proxy. Further studies such as Cenesizoglu and Grass (2018) refined this concept to distinguish between bid-side liquidity and ask-side liquidity. Despite this, the bid-ask spread also captures tendencies which are only indirectly related to liquidity since a considerable component of it is related to information asymmetries and the probability of informed trading (Glosten and Harris, 1988; Madhavan and Smidt, 1991).

Datar et al. (1998) used the turnover rate as a liquidity proxy - the ratio of the number of shares traded to the number of shares outstanding. Amihud (2002) proposed an illiquidity ratio which serves as a proxy for the price impact of a transaction; again, the concept is related to the idea that traders expect a compensation which is negatively related to the liquidity of an asset. Given that the former proxies are measuring the same aspect - liquidity - one should note that there are important connections between them. For instance, Chordia et al. (2006) reported strong links between trading volume and the bid-ask spread.

\subsection{Trading activity influencers}

Prior literature suggests that the level of trading activity and liquidity may be influenced by various factors as outlined below.

Security prices. Santosa and Laksana (2011) found that trading activity in stocks may be sensitive to the absolute level of the security price, and similarly Heflin and Shaw (2000) reported that the spread is negatively correlated to share prices.

Volatility. Studies such as Tinic (1972) found a negative relation between trading activity and volatility, while Stoll (1978), Jegadeesh and Subrahmanyam (1993) and Heflin and Shaw (2000) reported that the bid-ask spread is positively correlated with volatility. One possible reason accounting for the latter relationship is that more volatile stocks imply higher uncertainty which amplifies adverse selection problems. Nonetheless, some particular investors (including institutional ones) may prefer to trade higher volatility stocks, possibly because they offer a potential for higher profits (Falkenstein, 1996; $\mathrm{Ng}$ and $\mathrm{Wu}, 2006$ ). Conversely, other fund managers may prefer low volatility stocks (Pinnuck, 2004).

Trading setup features. Trading activity may also be influenced by the trading system and related protocols. Kalay et al. (2002) reported higher trading volumes for Tel Aviv Stock
Determinants of securities trading activity 
JCMS

3,1

Exchange securities which shifted to continuous trading, and lower volumes for those stocks which remained in the call auction system. Camilleri and Green (2009) found that following the suspension of the opening and closing call auctions on the National Stock Exchange of India, there were higher trading volumes which exceeded the typical upward trends over time. Masoud (2013) reported that the conversion to an electronic trading system on the Amman Stock Exchange in the year 2000 resulted in higher trading volumes. Similarly, Y1lmaz et al. (2015) found that systems upgrades in various emerging markets resulted in higher trading activity and lower spreads. In the context of the introduction of the hybrid market by the New York Stock Exchange, Hendershott and Moulton (2011) noted that the increased automation resulted in a reduction of order execution time but increased the spread. Gresse (2017) concluded that liquidity may be sensitive to competition between multiple-trading venues and the degree of algorithmic trading.

Cross-listings. Studies such as Correia and Amaral (2014), Pagano et al. (2002) and Moel (2001) suggested that securities liquidity is also affected by decisions to cross-list on overseas markets, partly as trading venues are pressured to upgrade their standards to avoid listed shares migrating to overseas markets.

Financing structure of the firm. The capital structure and financial leverage of a firm may also be related to the liquidity of its shares. For instance, Lipson and Mortal (2009) contended that since investors require a lower return from liquid stocks, the latter firms may be more inclined to issue equity. On the other hand, Lesmond et al. (2008) found that as firms substitute debt for equity, information asymmetry gets more pronounced and therefore the cost of liquidity is likely to increase.

Shareholding composition. The ownership concentration and the degree to which institutional investors hold equity in the firm may also influence liquidity. For instance, Amihud and Mendelson (2000) and Pham et al. (2003) contended that ownership dispersion is likely to raise liquidity. Similar tendencies were noted by Kale and Loon (2011) and Acedo et al. (2008). Dang et al. (2019) reported that stocks with higher institutional ownerships experienced higher liquidity shocks in the aftermath of the 2008 financial crisis. Heflin and Shaw (2000) found that spreads are positively related to ownership concentration.

Corporate governance and company management. The studies by Correia and Amaral (2014) and Chung et al. (2010) suggested that the shares of firms which adopt higher corporate governance standards are more liquid. Goh et al. (2009) contended that this is mainly attributable to a resulting reduction of agency problems. Aspara (2013) analysed the trading choices of a sample of individual investors and found that the quality of management is likely to impact on such decisions. Other studies suggested that securities tend to be more liquid when the underlying assets of the firm are more liquid as well (Gopalan et al., 2012; Correia and Amaral, 2014).

Serial dependencies. Various studies suggest specific tendencies in trading activity and liquidity across time. Authors such as Mcinish and Wood (1992) reported that trading volume and the spread are higher at the initial phase of the trading day and just before the closing of the session. Chordia et al. (2003) focussed on market-wide liquidity on the New York Stock Exchange for the period 1988-1998 and found that trading activity varied across days of the week and increased prior to particular macroeconomic announcements. Other studies which suggested that trading activity differs across weekdays include Foster and Viswanathan (1990, 1993).

Other features. Friewald et al. (2017) analysed data for the US structured product market and reported that securities which are mainly traded by institutions, and those that have lower credit risk tend to be more liquid.

In this study, we focus on the following five characteristics and inquire whether they influence the trading activity of our sampled stocks. 
Market capitalisation (CAP). The connection between CAP and liquidity was investigated since Demsetz (1968) found that firm size, trading volume and trading frequency rank amongst the main determinants of liquidity. The literature proposed that one may expect a positive relationship between firm size and liquidity given that larger firms attract more investors' attention and scrutiny from analysts (Merton, 1987) and in addition the securities of larger firms are less prone to information asymmetry (Harris, 1994). Similarly, large-cap stocks are characterised by more information flows, wider analyst coverage and higher market efficiency (Looi and Gallagher, 2006). As per the empirical study of Bhushan (1989), trading volumes are positively related to analysts' coverage. In addition, the largest stocks are more likely to be included in a market index and this causes additional trading activity as portfolios get rebalanced to reflect changes in index compositions (Greenwood and Sosner, 2007). A further reason why one may expect higher trading activity in large-cap stocks is the "flight-to-quality" behaviour which increases the trades in the most prominent securities when investors get nervous about economic prospects (Apergis et al., 2015). Conversely, in case of intermediated markets, the tendency for lower competition between market-makers in the context of smaller-cap stocks may contribute towards higher spreads (Bessembinder and Kaufman, 1997).

Such positive relationship between trading activity and firm size was confirmed in empirical studies such as Amihud and Mendelson (1986), Stoll (2000) and Bessembinder (2003) and it was analysed in theoretical models such as Lo and Wang (2006). Heflin and Shaw (2000) observed that the spread is negatively correlated to firm size. In their analysis of US stocks for the period 1963-2002, Chordia et al. (2007) found that firm size, together with other variables, is significant in explaining subsequent trading activity. Similarly, Francisco (2010) studied a sample of Brazilian equities for the period 1995-2010 and empirically found that liquidity is positively correlated with firm size and the number of shares in issue. Alnaif (2014) reported that for a sample of stocks trading on the Amman Stock Exchange during the period 2011-2013, CAP was positively related to stock market liquidity. Collver (2014) reported larger spreads for small-CAP stocks in the US markets. Pinnuck (2004) and $\mathrm{Ng}$ and $\mathrm{Wu}$ (2006) analysed trading trends on the Australian and the Chinese markets, respectively, and found that institutional investors prefer high CAP stocks. Thus, the literature seems to converge on a positive relationship between trading activity and CAP.

Dividend yield (DY). Empirical evidence, such as Griffin (2010) and Na'ura (2016), pointed at a negative connection between DY and stock liquidity, possibly due to a likelihood of firms paying higher dividends as a compensation for lower share liquidity. A further possible relationship between DY and trading activity lies in dividend-capture strategies, whereby traders hold stocks for a brief period during which they expect to earn a cash dividend. Karpoff and Walkling (1990) confirmed that dividend-capture strategies may explain salient tendencies in the behaviour of NASDAQ stocks. Given that dividend-capture strategies tend to be transaction-intensive, they become more viable in case of stocks that pay higher dividends. In this way, these strategies tend to induce a positive relationship between DY and trading activity. Therefore the two former effects run in opposite directions.

Correia and Amaral (2014) focussed on shares which traded on the São Paulo Stock Exchange between 1995 and 2010 and reported that less liquid stocks were more likely to pay higher dividends. Banerjee et al. (2007) empirically found an inverse relationship between a firm's stock liquidity and its dividend payouts, and even argued that from the point of view of traders, dividends and liquidity are considered as substitutes. Despite this, such tendencies were not confirmed in the context of the Korean market in a study by Lee and Yoon (2017). Alnaif (2014) found that during the period 2011-2013, dividends did not significantly impact on the liquidity of stocks comprising the Amman Stock Exchange Index. Ghodrati et al. (2014) analysed this relationship for a sample of firms traded on the Tehran Stock Exchange and
Determinants of securities trading activity 
JCMS

3,1

52

found that the nature of the relationship between liquidity and dividend payouts was sensitive to the adopted liquidity proxy. Similarly, the connection between dividend policies and securities behaviour may be sensitive to the selected dividend proxy (Camilleri et al., 2019). Overall, the finance literature does not point at an unambiguous direction regarding the relationship between DY and trading activity.

Earnings yield (EY). EYs may be expected to take a central role in terms of determining the trading decisions of market participants. Indeed, stocks are bought with the intention of participating in the earnings of a firm. These notions are confirmed by Kim and Verrecchia (1994) who reported that earnings announcements are likely to lead to increased trading volumes as traders react to the disclosed information.

Assuming that investors behave in a rational way, they prefer high profitability firms and therefore one may expect them to rebalance their portfolios in line with profitability ratios, thus causing higher trading activity. The empirical study by Correia and Amaral (2014) illustrated how the return on sales for Brazilian shares was positively related to liquidity in terms of the bid-ask spread. Alnaif (2014) considered the stocks comprising the Amman Stock Exchange Index for the period 2011-2013 and reported that the earnings per share was positively related to different proxies of liquidity.

Kale and Loon (2011) found a connection between stock liquidity and market power of the firm, explained by the possibility that firms which enjoy higher market power are more likely to influence product prices and therefore their stock value is less influenced by order flow. In their study they measured market power as the relationship between profitability and market share; and this suggests a positive connection between stock liquidity and company profitability. Somewhat pertinent is the empirical evidence presented by Atawnah et al. (2018) conveying a negative relationship between stock liquidity and foreign competition.

Nonetheless, one may also argue that stock trading on the basis of firm profitability constitutes very rational trading and therefore this category of transactions is likely to be less prone to excessive trading based on sentiment or overreaction - in this way profitability characteristics may also be negatively related to trading activity, as empirically found by Khan et al. (2016) in the context of the Malaysian market. Therefore, the positive relationship between EY and trading activity conveyed by a cross-section of studies is not universally supported across the literature.

Growth rate (GR). Finance conventions distinguish between growth stocks and value stocks, and investors may have different preferences in their stock selection process. Companies which register higher GRs are inherently attractive, yet they often trade at a premium and therefore some investors may prefer value stocks. In this way, the GR of an entity may affect the trading activity of the security. GRs are reported in the finance press, and those entities registering the highest growth may become more closely followed. As per Merton (1987) and Falkenstein (1996), a stock's visibility attracts additional investors. Furthermore, GR may elicit portfolio rebalancing decisions, for instance when traders divest of lower-growth entities (Lu et al., 2016). The GR of firms are likely to affect share prices, since the latter are responsive to the firms' profitability and expected future growth. Share trading activity may also be affected as per the model of Bagwell (1991) where tax-considerations imply that traders who experience a capital gain following higher GR, have a disincentive to sell shares whereas those who experience losses may be more inclined to sell their holdings. In the context of the New York Stock Exchange, Sum (2013) found that during the period 1951-2012, profit growth and share turnover Granger caused each other, and impulse response functions suggested an initial positive reaction on part of turnover to profitability fluctuations, which may change at subsequent stages. Overall, the direction of the relationship between GR and trading activity is still unresolved, partly due to the fact that some investment styles favour growth stocks whereas others do not. 
Established firms vs recently listed ones (YRS). Various studies suggest that the liquidity of newly listed firms may differ from that of more established ones. According to Booth and Chua (1996), IPOs may be underpriced in order to achieve trading interest from a wide crosssection of investors and this tends to boost the liquidity of newly listed firms. Empirical evidence which supports this hypothesis was presented by Pham et al. (2003) in the context of Australian IPOs and Zheng and Li (2008) for NASDAQ IPOs. Chordia et al. (2007) found that younger firms were more actively traded on the US markets during the period 19632002. In the context of Chinese stocks, $\mathrm{Ng}$ and $\mathrm{Wu}$ (2006) reported that institutional investors prefer recently listed firms.

Despite this, some investment philosophies such as those proposed in the classic treatise by Benjamin Graham and subsequent followers (Graham and Zweig, 2006), tend to favour investing in more established stocks with consistent dividend payments, since these are considered as more robust in terms of their ability to withstand temporary economic turmoil. This would suggest that established firms are more actively sought by traders, although such preference does not automatically imply additional trading activity if investors opt to hold such stocks for prolonged periods rather than trading them. Such notions may explain the mixed evidence found by Ghadamyari et al. (2017) who compared newly listed firms with more established ones traded on the Tehran Stock Exchange. The authors noted that newly listed firms were more liquid during a recessionary period, yet there was no significant difference between groups in a growth period. Overall, the finding that newly listed firms are more actively traded is not confirmed across all prior studies.

\section{Methodology}

In this study, we used different ordinary least squares models to inquire which possible trading activity determinants are significantly related to the cross-sectional variation in the turnover of the sampled stocks. We estimated regressions both for the individual markets as well as for the entire sample so that any divergent tendencies across exchanges may be detected, but at the same time we avoid confining the empirical evidence to one particular location.

We also laid particular importance on robustness checking in order to ensure the veracity of the reported results. In particular, we used two-step cluster analysis to sub-divide the sampled stocks into three groups to inquire whether results differ across sub-samples. As an additional form of robustness checking, we estimated more than one version of most models, in order to minimise the possibility that data sampled across different exchanges might prove incompatible. For instance, given that the CAP may differ materially across the sampled venues, the original data were transformed in different ways to obtain more consistent yardsticks. Therefore, in some estimations we used CAP as a percentage of the total market CAP for the respective exchange, while in other models we took the CAP rankings of the sampled stocks within the particular market. In those cases where we do not report all the estimations, we disclose the model which features the highest explanatory power.

Finally, we used factor analysis to re-group the liquidity determinants into factors to obtain a more succinct insight regarding trading activity influencers. Factor analysis is a data reduction technique which groups a number of related variables into a smaller number of factors, so that one may identify tendencies which may be difficult to discern in larger data sets.

\section{Data}

Our sample was collated through a selection of 172 stocks trading on the London Stock Exchange, the Madrid Stock Exchange, the Malta Stock Exchange and the Vienna Stock Exchange as at October 2017. We selected these four European trading venues to capture a cross-section of well-established and novel markets with a diverse background.
Determinants of securities trading activity 
JCMS 3,1

As per the Federation of European Stock Exchanges (2017), the turnover for these markets for the month of October 2017 was as follows: London Stock Exchange - Euro 170,641m; Madrid Stock Exchange - Euro 62,089m; Vienna Stock Exchange - Euro 2,887m; and Malta Stock Exchange - Euro 12m. When these turnover statistics were ranked from highest to lowest amongst 22 European markets for which data were available from the same source, the sampled exchanges ranked as follows: London Stock Exchange - 1; Madrid Stock Exchange - 7; Vienna Stock Exchange - 11; Malta Stock Exchange - 20. Similarly, as per the World Economic Forum (2017), we may note that the sampled markets feature a comprehensive range of rankings (amongst 137 countries) in terms of the likelihood of companies to issue securities: UK - 3; Austria - 28; Malta - 29; and Spain - 65. This suggests that our sampled venues capture a diversity of sizes and stages of development.

We randomly selected 50 stocks trading on each exchange, except for the Malta Stock Exchange where the number of listed securities stood at 22 and therefore, we included all the stocks. All equities traded on a particular stock exchange were observed on a specific day for the sake of consistency, as specified below. Data were obtained from the websites of the exchanges, and other firm-specific information was obtained from the financial statements of the respective companies. The variables used in the estimated models were setup as outlined hereunder.

We selected the turnover (in currency) for each sampled stock on a given day as a proxy for trading activity, as detailed below. This yardstick was regularly used as a trading activity/liquidity proxy in prior studies such as Chordia et al. (2001), Glaser and Weber (2007) and Moriyasu et al. (2018). Indeed, Lo and Wang (2000) contended that share turnover is the most suitable indicator of trading activity, and it yields the clearest insights if two-fund separation theorem holds. In modelling trading activity, we started with the turnover for each company on the following days: 11 October 2017 for the London Stock Exchange, 31 October 2017 for the Madrid Stock Exchange, 4 October 2017 for the Malta Stock Exchange and 13 October 2017 for the Vienna Stock Exchange. Given that the yardstick was calculated as at these particular days, there is the possibility that such observations may not represent the usual volumes of a typical trading day, yet in view of the number of stocks which we consider we would not expect that such limitation ought to compromise the validity of the study[1]. The trading activity yardstick for each stock was then computed as the turnover for the stock as a percentage of the total equity turnover on the respective exchange on the particular day. Similarly, the CAP values for each stock were modelled as a percentage of the total CAP for the particular day. We computed percentages (rather than taking amounts in currency) to enable a better comparison across the respective markets, in view of the fact that the daily trading activity and typical CAP may vary considerably across the sampled stock exchanges[2]. DYs were extracted from the financial statements of the respective firms.

Since the EY and the company GRs were not readily available, they were computed using the following formulae:

$$
\mathrm{EY}=\text { Earnings Per Share }{ }_{2016} / \text { Share Price as at above sampling dates, }
$$

$$
\mathrm{GR}=\left(\operatorname{Rev}_{2016}-\operatorname{Rev}_{2015}\right) / \operatorname{Rev}_{2015},
$$

where $\operatorname{Rev}_{n}$ is the revenue of the firm for year $n$.

In order to distinguish between recently listed firms and more established ones, we created a dummy variable (YRS) which took a value of one in case of shares listed since five years or more and zero otherwise. 


\section{Estimations}

We commence our empirical analysis by estimating regressions for the respective stock exchanges, with trading turnover modelled as a function of the selected possible determinants. Results summarised in Table I show that CAP is the only significant variable in case of London, Madrid and Malta, whereas YRS is significant in case of Vienna[3].

When estimating further models on the entire sample of stocks, we applied different transformations to the data to address possible inconsistencies across markets. For instance, due to the differences in the number of stocks traded across the sampled exchanges, a given turnover percentage on one market could represent a different level of trading activity in the context of another exchange. In this way, we also estimated models where we used the trading activity rankings within the particular country, where the trading activity yardstick for each stock stood between 1 and 50[4]. In addition we estimated other models, where all the variables were converted to rankings (except for the dummy variable YRS where the possible values of 0 and 1 were already consistent across markets). Results reported in Table II show that the first version of the model (using the original data without any transformations) has the highest explanatory power, and the variables CAP and YRS are statistically significant in at least one model specification. This is somewhat in line with the insights obtained from the regressions estimated for the respective exchanges.

In order to check whether the latter results may differ materially across the stocks, we split the sample into three groups, using a two-step clustering procedure[5]. Summary information about the clusters is shown in Table III where we note that each cluster includes stocks from all the sampled countries. The first cluster is the one which has highest average trading activity, the highest average CAP of stocks and lowest EYs. The third cluster features the lowest trading activity and overall high GRs. All the stocks which were listed since less than five years (except for one case) were assigned to this group. Given that all stocks in the third cluster had a YRS dummy equal to 0 , and most stocks in the first and second cluster had a YRS dummy equal to 1 , this variable could not be used in the subsequent regressions for the clusters, given that it was practically constant within the respective groups.

\begin{tabular}{|c|c|c|c|c|c|c|}
\hline Intercept & GR & YRS & DY & $\mathrm{EY}$ & CAP $\%$ & \\
\hline \multicolumn{7}{|c|}{ London Stock Exchange } \\
\hline \multirow{3}{*}{$\begin{array}{l}-3.2 \mathrm{E}-07 \\
-0.09\end{array}$} & $4.6 \mathrm{E}-10$ & $2.3 \mathrm{E}-06$ & $-9.2 \mathrm{E}-07$ & $7.7 \mathrm{E}-09$ & $5.1 \mathrm{E}-05$ & \\
\hline & 0.04 & 0.58 & -0.85 & 0.11 & $10.73^{* * * *}$ & \\
\hline & $R^{2}=0.7351$ & & & Adjusted $R^{2}=0.7050$ & & \\
\hline \multicolumn{7}{|c|}{ Madrid Stock Exchange } \\
\hline \multirow{3}{*}{$\begin{array}{l}-6 \mathrm{E}-05 \\
-0.33\end{array}$} & $5 \mathrm{E}-07$ & $2 \mathrm{E}-05$ & $-4 \mathrm{E}-05$ & $-7 \mathrm{E}-07$ & 13.4354 & \\
\hline & 0.34 & 0.09 & -1.22 & -0.13 & $9.19^{* * * *}$ & \\
\hline & $R^{2}=0.6654$ & & & Adjusted $R^{2}=0.6273$ & & \\
\hline \multicolumn{7}{|c|}{ Malta Stock Exchange } \\
\hline 3.4468 & 0.1167 & -0.4802 & -0.5215 & -0.1988 & 0.5398 & \\
\hline \multirow[t]{2}{*}{$1.83^{*}$} & 0.92 & -0.23 & -0.74 & -1.24 & $2.74 * *$ & \\
\hline & $R^{2}=0.4072$ & & & Adjusted $R^{2}=0.2219$ & & \\
\hline \multicolumn{7}{|c|}{ Vienna Stock Exchange } \\
\hline \multirow{2}{*}{$\begin{array}{l}-0.1763 \\
-0.27\end{array}$} & 0.0049 & 2.4548 & 0.0920 & -0.0242 & 0.0596 & \\
\hline & $\begin{array}{c}0.38 \\
R^{2}-03095\end{array}$ & $3.71^{* * * *}$ & & $\begin{array}{l}-1.05 \\
\text { Adiusted } R^{2}=02310\end{array}$ & 0.17 & Table I. \\
\hline \multicolumn{6}{|c|}{$\begin{array}{l}\text { Notes: Coefficients are shown on top and } t \text {-ratios are reported underneath. *******Significant at the } 90,95 \\
\text { and } 99 \text { per cent levels of confidence, respectively }\end{array}$} & $\begin{array}{r}\text { Trading activity } \\
\text { regressions for } \\
\text { individual exchanges }\end{array}$ \\
\hline
\end{tabular}

Determinants of securities trading activity 
JCMS

3,1

56

Table II.

Trading activity regressions for entire sample (three different versions)

\begin{tabular}{lccccc}
\hline Intercept & GR & YRS & DY & EY & CAP\% \\
\hline Dependent variable specified as \% trading turnover & & & & \\
0.1329 & -0.0004 & 0.6574 & -0.0937 & -0.0014 & 0.6394 \\
0.45 & -0.26 & $2.09 * *$ & -1.28 & -0.15 & $10.57 * * *$ \\
& $R^{2}=0.4187$ & & & Adjusted $R^{2}=0.4012$ &
\end{tabular}

Dependent variable specified as trading turnover rank

14.5117

$6.96 * * *$

$0.0092 \quad 12.7065$

$0.75 \quad 5.68^{* * * *}$

$R^{2}=0.1964$

0.7181

1.38

0.0745
1.15
Adjusted $R^{2}=0.1722$

0.6188

1.44

All Variables specified as ranks (except YRS dummy variable)
3.9403
1.10
0.0468
2.7512
0.96
0.0832
0.0599
0.73
0.4811
$R^{2}=0.3433$
1.16
Adjusted $R^{2}=0.3150$
$5.79^{* * * *}$

Notes: Coefficients are shown on top and $t$-ratios are reported underneath. ******Significant at the 95 and 99 per cent levels of confidence, respectively
Table III.

Summary information for the three clusters

\begin{tabular}{lccc}
\hline & Cluster 1 & Cluster 2 & Cluster 3 \\
\hline Number of Stocks & 18 & 103 & 51 \\
London Stock Exchange & 6 & 33 & 11 \\
Madrid Stock Exchange & 2 & 40 & 8 \\
Malta Stock Exchange & 8 & 9 & 5 \\
Vienna Stock Exchange & 2 & 21 & 27 \\
& Average & Average & Average \\
Trading turnover \% & 4.032 & 0.609 & 0.335 \\
GR & $5.566^{*}$ & 7.529 & 22.796 \\
DY \% & 0.931 & 2.043 & 1.568 \\
EY \% & -4.621 & 4.938 & 4.058 \\
CAP \% & 4.399 & 0.184 & 0.578 \\
YRS & 0.944 & 1.000 & 0.000
\end{tabular}

Notes: *The reported growth average for Cluster 1 was computed after eliminating an outlier observation. When including the outlier observation, the GR for this cluster was 60.8 per cent

We estimated three different models for each cluster, using data in their original format and other estimations featuring the transformations noted above. For the sake of brevity, we only report the version using original data since it achieved the highest collective explanatory power (Table IV). CAP is the variable which features the highest level of significance in these models; in case of the second and the third cluster it is significant at the 95 and 99 per cent levels, respectively, whilst in the first cluster it registered the highest $t$ ratio. As for the other estimations which we do not report in the table, DY was significant at the 90 per cent level in one estimation for the first cluster, whereas CAP was significant at the 99 per cent level in an estimation on the second cluster, and at the 90 per cent level in an estimation for the third cluster.

Given that the first cluster only comprised 18 stocks, and that one evident difference between clusters was in terms of the dummy variable YRS, we also split the entire sample in two groups - the first one with stocks listed since less than five years, and another comprising stocks with an earlier listing. We re-estimated a series of regressions using these two different sub-samples; again, omitting the variable YRS since its value was uniform within the sub-groups. As previously, we estimated three different versions of the model for 


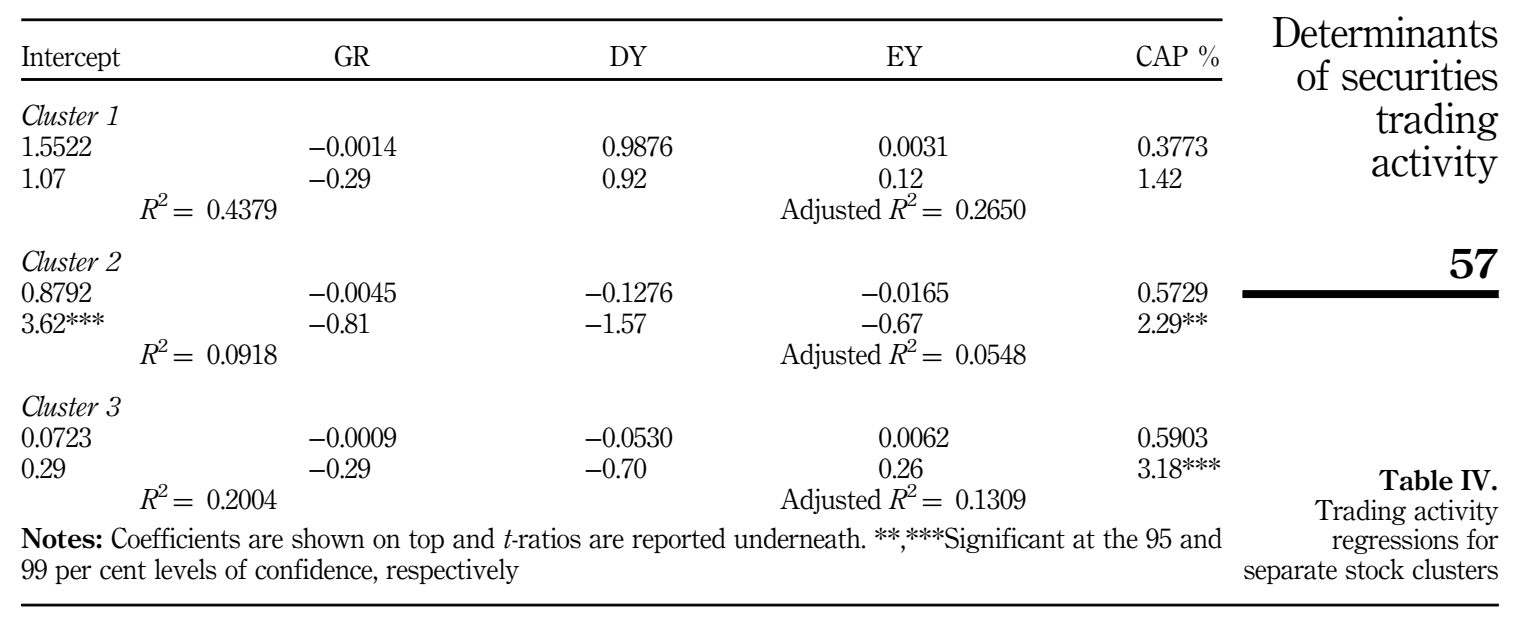

each group but report the one using untransformed data since it featured the highest explanatory power overall. As shown in Table V, CAP is significant at the 99 per cent level of confidence for both groups, whereas the other variables are insignificant.

As a final step in our inquiry, we used factor analysis to convert the variables into a smaller number of factors to estimate more succinct models. In factor analysis, it is particularly important that the variables are consistent with one another, and therefore we used the rank data for all variables except the dummy YRS. In case of the latter variable, we scaled it proportionally to the ranks by assigning a value of 17 for the zero observations, and a value of 33 for the one observations. Before estimating the factors using the Principal Axis Method, we checked the Kaiser-Meyer-Olkin Measure of Sampling Adequacy which was 0.540 and the $p$-value of the Bartlett's Test of Sphericity which was 0.0009, indicating that the pre-conditions to conduct a meaningful factor analysis were satisfied. The variables were grouped into two factors as shown in Table VI Panel A. Factors 1 and 2 account for 23.3 and 8.6 per cent of the variation in the data, respectively.

Factor 1 is mostly correlated with DY, EY and CAP and given that all these variables were modelled as ranks and positively loaded in the factor, they were added together to be modelled as a single variable. Both the yields and CAP are related to the profitability of a firm, and we therefore label this factor as "Profitability". Factor 2 is mainly correlated to the other two variables: GR (which is positively loaded) and YRS (which is negatively loaded). The fact that the two variables run in the opposite direction within this factor, could be

\begin{tabular}{|c|c|c|c|c|}
\hline Intercept & GR & DY & EY & $\mathrm{CAP} \%$ \\
\hline \multicolumn{5}{|c|}{ Stocks listed since less than five years } \\
\hline 0.0584 & -0.0001 & -0.0518 & 0.0043 & 0.5966 \\
\hline \multicolumn{2}{|c|}{$R^{2}=0.2002$} & -0.69 & $\begin{array}{l}0.19 \\
\mathrm{~d} R^{2}=\end{array}$ & $3.28^{* * *}$ \\
\hline
\end{tabular}

Stocks listed since five years or more

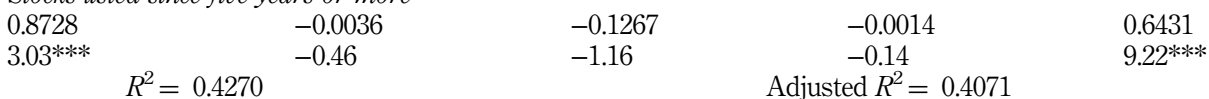

Notes: Coefficients are shown on top and $t$-ratios are reported underneath. ***Significant at the 99 per cent level of confidence

Table V. Trading Activity regressions for stocks grouped by the number of years listed 
JCMS

3,1

58

Grouping the variables into factors
Panel A: factor loadings

Variable

YRS

DY rank

EY rank

CAP rank

GR rank

Panel B: trading activity regression using factors as explanatory variables Intercept

17.5271

$7.25^{* * * *}$

$R^{2}=0.1456$

Factor 1: profitability

0.1294

$4.35^{* * * *}$

Adjusted $R^{2}=0.1355$

Notes: Factor 1 was specified as the addition of the ranks of DY, EY and CAP; Factor 2 was specified by multiplying the YRS dummy variable value by 25 and subtracting the result from the GR rank (refer to Notes 5 and 6); coefficients are shown on top and $t$-ratios are reported underneath. ***Significant at the 99 per cent level of confidence

related to the conjecture that newly established firms enjoy higher GRs. We therefore label this factor as "Track Record". We combine the two variables in a single factor by multiplying the YRS dummy value by 25, and then subtracting the answer from the growth rank for each firm[6]. In this way the GR rank was adjusted to take the YRS dummy variable into account, using a metric value which is comparable to the former $\operatorname{rank}[7]$. We then estimated a regression where the dependent variable was the trading turnover rank, and the two factors were specified as explanatory variables. Results shown in Table VI Panel B indicate that both factors are significant at the 99 per cent level.

In Table VII we summarise the statistical significance of the variables which were included in all the above estimations. It is evident that CAP is the variable which proved significant in most models, and YRS ranks thereafter. DY was significant in two estimations which were not reported for the sake of brevity.

The main empirical findings may be summarised as follows:

- when modelling the trading activity determinants for the separate exchanges, CAP was the only significant variable in case of the London, Madrid and Maltese markets, whereas YRS was the only significant determinant in case of the Viennese market;

- assessing the determinants using the combined data set, their significance differed depending on the transformations done to the data, however, CAP emerged as the determinant with highest significance, whilst YRS ranked thereafter;

- when splitting the sample into three clusters, CAP retained its prime importance as a trading activity determinant;

- similarly, CAP remained the only significant variable after splitting the entire sample in terms of stocks listed since less than five years, vs others; and

- when the determinants were grouped together through factor analysis, the emerging factors which we called "Profitability" and "Track Record" were both significant at the 99 per cent level in accounting for the cross-sectional variation in trading activity.

These insights are further discussed in the concluding section.

\section{Conclusion}

This study focussed on stock trading turnover to investigate the relative importance of five possible trading activity determinants: CAP, DY, EY, GR and YRS. We compiled a sample of 


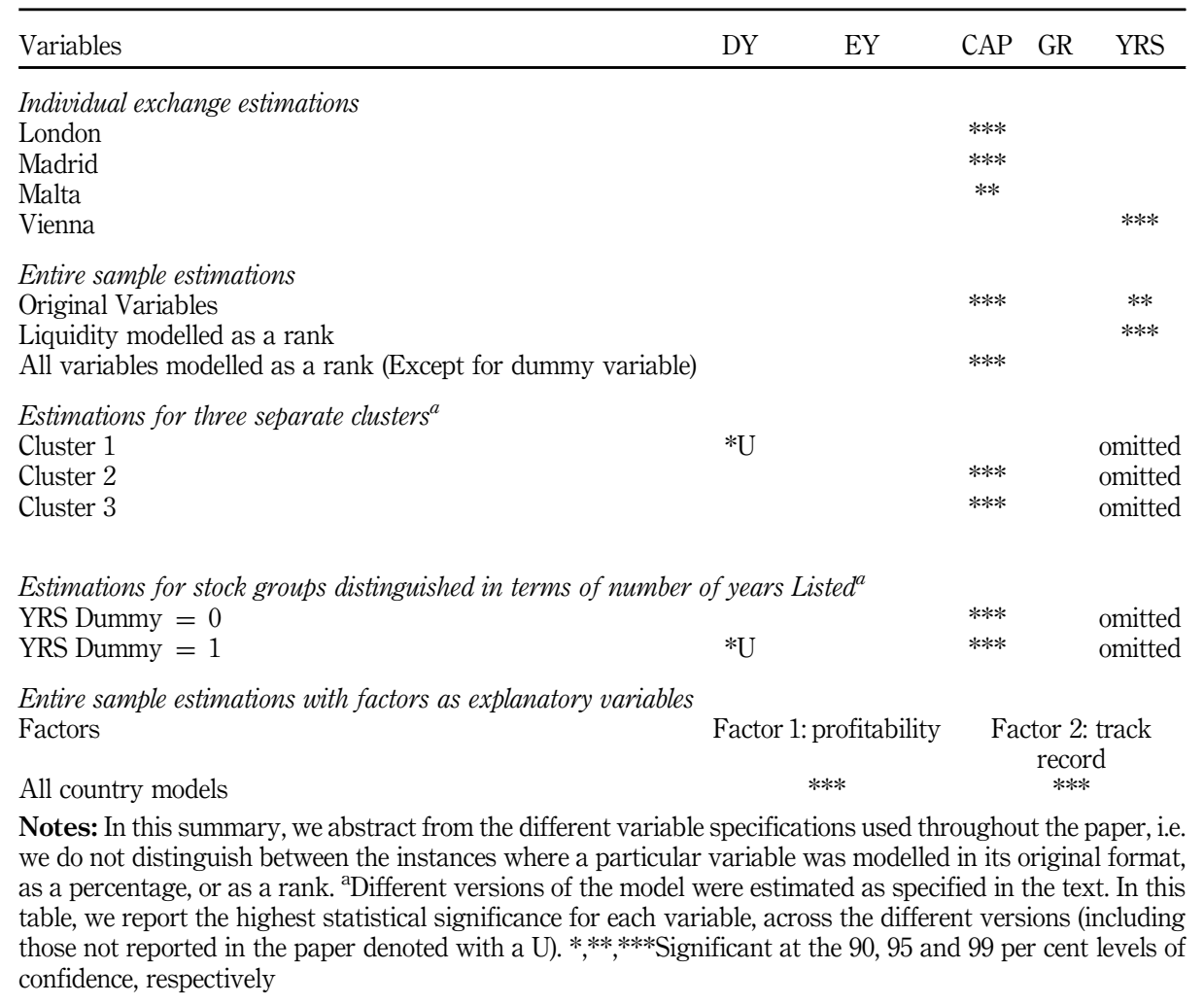

Determinants of securities trading activity

172 equities which traded on four different exchanges during October 2017: London Stock Exchange, Bolsa De Madrid, Malta Stock Exchange and Vienna Stock Exchange. These four venues capture a variety of liquidity levels and stages of market development within the European context. In view of the differences in trading activity across these venues we also transformed the variable data into rankings, although we obtained higher explanatory power using data in their original format. We estimated models both for the individual exchanges as well as on the whole sample. In addition, we split the sample in two different ways to inquire about the consistency across sub-groups.

Overall, our results suggest that market capitalisation is the characteristic which mostly explains the cross-sectional variation in trading activity, and we noted a positive relationship in line with prior studies. The difference between established and newly listed firms (approximated by the dummy variable YRS) also proved significant in a number of estimations, and it may be ranked as the second most important in our sample. Despite this, the variable was omitted in the estimations on the sub-samples since the latter featured a practically uniform cross-section of its possible binary observations. In most estimations, the sign of the coefficient suggests that recently listed firms are less actively traded, although this was not applicable to all trading venues. This echoes the mixed insights of prior literature. It is pertinent to mention that dividends (approximated by the variable DY) were significant at the 90 per cent level in two estimations which we did not report for the sake of brevity, and in these cases, there was a positive relationship. This runs counter to the traditional thought that higher dividends serve as a compensation for lower liquidity (Griffin, 2010). 
JCMS

3,1

60

We also applied factor analysis to re-group the variables into two factors using the Principal Axis Method. The first factor which we called "Profitability" comprised DY, EY and CAP and was positively related to trading activity. The second factor comprised the other two variables: GR (which was positively loaded) and YRS (which was negatively loaded). We conjectured that this could be related to the possibility that newly established firms enjoy higher GRs. We labelled this factor as "Track Record" and it proved negatively related to trading volumes; suggesting that older listings attract more trades whilst growth stocks attract less trading volumes (possibly due to higher perceived risk). Both the "Profitability" and "Track Record" factors were highly significant in explaining the cross-sectional variation in trading activity.

We believe that this research area and our results in particular are of noteworthy pertinence to market practitioners. One main factor which explains the interest in trading volumes is that it constitutes an important determinant of liquidity (Brennan and Subrahmanyam, 1996) and the latter may be expected to affect asset prices (Bekaert et al., 2007) and the cost of capital from the point of view of securities issuers (Amihud and Mendelson, 1986). Trading volumes and liquidity are of central importance for exchanges since they directly impact on generated revenues and account for the relative standing of the venues across the financial sphere. Traders are also interested in volumes and liquidity since these impact on the trading costs and overall feasibility of a strategy. Traders who are interested in the longer-term liquidity of an asset may get an indication as to whether the current liquidity levels are sustainable in view of the liquidity determinants which we explored in this paper. Similarly, trading venues, securities underwriters and prospective issuers may formulate opinions about the subsequent liquidity of an issue of securities by analysing such determinants together with others. Hereunder, we discuss select insights of this study in the context of the individual characteristics and the policies adopted by the respective trading venues comprising our sample.

\subsection{The London Stock Exchange}

This venue is the most prolific amongst the sampled ones in terms of turnover and trading history. As exchanges mature, they often seek to get involved in additional products such as exchange-traded funds and derivatives. In this way, the liquidity and related pricing process of securities takes on a new importance in the context of this exchange, as these are likely to form the underlying basis of novel product lines.

\subsection{The Madrid Stock Exchange}

Assessing the trading activity levels of prospective securities issues may be particularly important in case of this venue, given that as per the World Economic Forum (2017), Spain ranks rather low in terms of the likelihood of companies to issue securities, as compared to the other venues in our sample. Given this, trading activity determinants may be used to attract or to offer incentives to the category of entities which is most likely to generate trading interest.

\subsection{The Malta Stock Exchange}

This venue is one of the smallest in Europe, and there may only be limited potential for new listing activity in view of the island's small economy. In this way, the venue's efforts to attract trading activity from overseas entities is sensible. One way in which such objective is being pursued is through the "Prospects" multilateral trading facility, where new start-ups may raise funding, at least until they develop the track record entailed to enlist on the main market. Indeed, as per our results the "Track Record" factor was a highly significant determinant of trading activity, and therefore the overall viability of a securities issue.

\subsection{The Vienna Stock Exchange}

In case of this venue, our results point at different trends when compared to other markets, in that the main liquidity determinant was the number of years listed, rather than capitalisation. 
This suggests that different markets may vary in terms of their characteristics, and therefore venues should avoid the replication of policies adopted by peers, in the absence of a thorough evaluation.

The above insights should be interpreted in the context of the limitations of this study. In particular, the data for the respective markets were compiled as a snapshot on a specific trading day which may not be representative of the underlying behaviour of the sampled stocks. In addition, one would expect trading activity to be influenced by additional elements such as company announcements and utilitarian trading which we do not account for in this paper. Similarly, various other aspects could impact on stock trading within a particular venue and these include spillovers in between markets (Cuardo Sáez et al., 2009; Camilleri, 2010), behavioural biases (Gervais and Odean, 2001; Khan et al., 2016), the difference between newly setup markets and more established ones (Miles, 2005; Camilleri and Galea, 2009), the trading setup (Hendershott and Moulton, 2011; Camilleri, 2015) and seasonality (Camilleri, 2008; Shahani and Sharma, 2018).

Our results also point at further research potential. In particular, the observation that DYs, EYs and GRs did not emerge as important trading activity determinants could be counter-checked by additional research considering other markets. A possible refinement on our methodology may be the application of data envelopment analysis, where the trading activity may be treated as an "output" whereas the determinants are modelled as "inputs". In this way, one could analyse the characteristics of the group of stocks which lies near the "efficient frontier" as opposed to others. In addition, the availability of larger data sets offers further potential for using data mining techniques to better understand how the former liquidity determinants together with others, interact to influence the trading process. In addition, researchers may investigate any heterogeneity effects in between markets by accounting for the differences in the respective trading procedures.

\section{Notes}

1. It is unlikely that several stocks experience atypical behaviour simultaneously in the absence of abnormal events. We therefore double-checked our sampling days to ensure that these did not coincide with such occurrences. No abnormal events were noted during the sampling days, although in case of Spain, the referendum relating to the independence of Catalonia caused market concerns, and some listed firms announced their intention to re-locate out of the region during the earlier days of the month. The empirical results reported subsequently in the paper suggest that in case of the Madrid Stock Exchange, the trends which we are interested in were essentially in line with those of other sampled venues. This provides reassurance that the former occurrence did not exert material impacts on the main insights emanating from our study.

2. In those cases where exchanges did not provide a total turnover or market capitalisation for the particular trading day, the monthly total turnover or market capitalisation was divided by the 23 trading days to obtain a daily average.

3. We also estimated more succinct models for each country by successively eliminating the least significant variables, however, there were no further variables which proved significant in the subsequent estimations. In particular, despite the possible correlation between DY and EY, the latter variables were still insignificant when they were not included in the same model.

4. The ranks for Malta ran from 1 to 22 given that there were only 22 sampled stocks. To achieve rankings which are arithmetically comparable with those of the other countries, the ranks for Maltese stocks were divided by 22 and multiplied by 50 .

5. The clustering procedure took into account all the six variables used in this study and these were specified in their original version, with trading turnover modelled as a percentage.

6. The value 25 was chosen since it falls within the middle of the ranking range (1-50).
Determinants of securities trading activity 
JCMS

3,1

62

7. We tried different possible methods of combining these two variables in one factor, and we are reporting the version which resulted in the highest explanatory power in subsequent regression estimations.

\section{References}

Acedo, M., Ruiz, F.J. and Santamaria, R. (2008), "Influence of secondary offerings on the liquidity and trading activity of stocks outstanding", Czech Journal of Economics and Finance, Vol. 58 Nos 1-2, pp. 21-37.

Alnaif, K.L. (2014), "Stock liquidity determination: evidence from Amman Stock Exchange", Asian Economic and Financial Review, Vol. 4 No. 12, pp. 1894-1905.

Amihud, Y. (2002), "Illiquidity and stock returns: cross-section and time-series effects", Journal of Financial Markets, Vol. 5 No. 1, pp. 31-56.

Amihud, Y. and Mendelson, H. (1986), "Asset pricing and the bid-ask spread”, Journal of Financial Economics, Vol. 17 No. 2, pp. 223-249.

Amihud, Y. and Mendelson, H. (1991), "Volatility, efficiency and trading: evidence from the Japanese stock market”, The Journal of Finance, Vol. 46 No. 5, pp. 1765-1789.

Amihud, Y. and Mendelson, H. (2000), "The liquidity route to a lower cost of capital”, Journal of Applied Corporate Finance, Vol. 12 No. 4, pp. 8-25.

Apergis, N., Artikis, P. and Kyriazis, D. (2015), "Does stock market liquidity explain real economic activity? New evidence from two large European stock markets", Journal of International Financial Markets, Institutions and Money, Vol. 38, pp. 42-64.

Aspara, J. (2013), "The role of product and brand perceptions in stock investing: effects on investment considerations, optimism, and confidence", Journal of Behavioral Finance, Vol. 14 No. 3, pp. 195-212.

Atawnah, N., Balachandran., B., Duong, H.N. and Podolski, E.J. (2018), "Does exposure to foreign competition affect stock liquidity? Evidence from industry-level import data", The Journal of Financial Markets, Vol. 39, pp. 44-67.

Bagwell, L. (1991), "Share repurchase and takeover deterrence", The RAND Journal of Economics, Vol. 22 No. 1, pp. 72-88.

Banerjee, S., Gatchev, V.A. and Spindt, P.A. (2007), "Stock market liquidity and firm dividend policy", Journal of Financial and Quantitative Analysis, Vol. 42 No. 2, pp. 369-397.

Bekaert, G., Harvey, C.R. and Lundblad, C. (2007), "Liquidity and expected returns: lessons from emerging markets", Review of Financial Studies, Vol. 20 No. 6, pp. 1783-1831.

Bessembinder, H. (2003), "Issues in assessing trade execution costs", Journal of Financial Markets, Vol. 6 No. 3, pp. 233-257.

Bessembinder, H. and Kaufman, H.M. (1997), "A comparison of trade execution costs for NYSE and NASDAQ-listed stocks", Journal of Financial and Quantitative Analysis, Vol. 32 No. 3, pp. 287-310.

Bhushan, R. (1989), "Firm characteristics and analyst following", Journal of Accounting and Economics, Vol. 11 Nos 2-3, pp. 255-274.

Booth, J. and Chua, L. (1996), "Ownership dispersion, costly information, and IPO underpricing", Journal of Financial Economics, Vol. 41 No. 2, pp. 291-310.

Brennan, M.J. and Subrahmanyam, A. (1996), "Market micro-structure and asset pricing: on the compensation for liquidity in stock returns", Journal of Financial Economics, Vol. 41 No. 3, pp. 441-464.

Camilleri, S.J. (2008), "Month-related seasonality of stock price volatility: evidence from the Malta Stock Exchange", Bank of Valletta Review, Vol. 37, pp. 49-65. 
Camilleri, S.J. (2010), "Response of Indian equities to U.S. stock market movements of the prior trading day", in Gregoriou, G.N. (Ed.), Emerging Markets: Performance, Analysis and Innovation, CRC Press - Taylor and Francis Group, London, pp. 493-508.

Camilleri, S.J. (2015), "Do call auctions curtail price volatility? Evidence from the National Stock Exchange of India", Managerial Finance, Vol. 41 No. 1, pp. 67-79.

Camilleri, S.J. and Galea, G. (2009), "The diversification potential offered by emerging markets in recent years", The FEMA Research Bulletin, Vol. 1 No. 3, pp. 21-37.

Determinants

of securities trading activity

Camilleri, S.J. and Green, C.J. (2009), "The impact of the suspension of opening and closing call auctions: evidence from the National Stock Exchange of India”, International Journal of Banking, Accounting and Finance, Vol. 1 No. 3, pp. 257-284.

Camilleri, S.J. and Green, C.J. (2014), "Stock market predictability: non-synchronous trading or inefficient markets? Evidence from the National Stock Exchange of India", Studies in Economics and Finance, Vol. 31 No. 4, pp. 354-370.

Camilleri, S.J., Grima, L. and Grima, S. (2019), "The effect of dividend policy on share price volatility: an analysis of Mediterranean banks' stocks”, Managerial Finance, Vol. 45 No. 2, pp. 348-364.

Cenesizoglu, T. and Grass, G. (2018), "Bid- and ask-side liquidity in the NYSE limit order book”, Journal of Financial Markets, Vol. 38, pp. 14-38.

Chordia, T., Huh, S. and Subrahmanyam, A. (2007), "The cross section of expected trading activity", The Review of Financial Studies, Vol. 20 No. 3, pp. 709-740.

Chordia, T., Roll, R. and Subrahmanyam, A. (2003), "Determinants of daily fluctuations in liquidity and trading activity", Cuadernos de Economia, Vol. 40 No. 121, pp. 728-751.

Chordia, T., Roll, R. and Subrahmanyam, A. (2005), "Evidence on the speed of convergence to market efficiency", Journal of Financial Economics, Vol. 76 No. 2, pp. 271-292.

Chordia, T., Shivakumar, L. and Subrahmanyam, A. (2006), "The cross section of daily variation in liquidity", in Brick, I., Ronen, T. and Lee, C. (Eds), Advances in Quantitative Analysis of Finance and Accounting, World Scientific, NJ, pp. 75-110.

Chordia, T., Subrahmanyam, A. and Anshuman, R. (2001), "Trading activity and expected stock returns", Journal of Financial Economics, Vol. 59 No. 1, pp. 3-32.

Chung, K.H., Elder, J. and Kim, J.C. (2010), “Corporate governance and liquidity”, Journal of Financial and Quantitative Analysis, Vol. 45 No. 2, pp. 265-291.

Collver, C. (2014), A Characterization of Market Quality for Small Capitalization US Equities, US Securities and Exchange Commission, Washington, DC, available at: www.sec.gov/ marketstructure/research/small_cap_liquidity.pdf (accessed 4 December 2018).

Correia, L.F. and Amaral, H.F. (2014), "Determinants of market liquidity of shares traded on the BM and FBOVESPA", Brazilian Business Review, Vol. 11 No. 6, pp. 75-97.

Cuardo Sáez, L., Fratzscher, M. and Thinmann, C. (2009), "The transmission of emerging market shocks to global equity markets", Journal of Empirical Finance, Vol. 16 No. 1, pp. 2-17.

Dang, T.L., Moshirian, F. and Zhang, B. (2019), "Liquidity shocks and institutional investors", The North American Journal of Economics and Finance, Vol. 47, pp. 184-209.

Datar, V., Naik, N. and Radcliffe, R. (1998), "Liquidity and asset returns: an alternative test", Journal of Financial Markets, Vol. 1 No. 2, pp. 203-219.

Day, T.E. and Wang, P. (2002), "Dividends, nonsynchronous prices, and the returns from trading the Dow Jones industrial average", Journal of Empirical Finance, Vol. 9 No. 4, pp. 431-454.

Demsetz, H. (1968), "The cost of transacting", The Quarterly Journal of Economics, Vol. 82 No. 1, pp. 33-53.

Eleswarapu, V.R. (1997), "Cost of transacting and expected returns in the Nasdaq market", The Journal of Finance, Vol. 52 No. 5, pp. 2113-2127. 
JCMS

3,1

Elyasiani, E., Hauser, S. and Lauterbach, B. (2000), "Market response to liquidity improvements: evidence from exchange listings", The Financial Review, Vol. 35 No. 1, pp. 1-14.

Falkenstein, E.G. (1996), "Preferences for stock characteristics as revealed by mutual fund portfolio holdings", Journal of Finance, Vol. 51 No. 1, pp. 111-135.

Federation of European Stock Exchanges (2017), "European equity market report - 2017", available at: https://fese.eu/statistics/\#eemr (accessed 9 March 2019).

Foster, F. and Viswanathan, S. (1990), "A theory of the interday variations in volume, variance, and trading costs in securities markets", The Review of Financial Studies, Vol. 3 No. 4, pp. 593-624.

Foster, F. and Viswanathan, S. (1993), "Variations in trading volume, return volatility and trading costs: evidence on recent price formation models", Journal of Finance, Vol. 48 No. 1, pp. 187-211.

Foucault, T., Kadan, O. and Kandel, E. (2005), "Limit order book as a market for liquidity", Review of Financial Studies, Vol. 18 No. 4, pp. 1171-1217.

Francisco, P. (2010), "Liquidez e características intrínsecas das acções - o caso do mercado europeu”, Cadernos do Mercado de Valores Mobiliários, Lisbon.

Friewald, N., Jankowitsch, R. and Subrahmanyam, M.G. (2017), "Transparency and liquidity in the structured product market”, The Review of Asset Pricing Studies, Vol. 7 No. 2, pp. 316-348.

Gervais, S. and Odean, T. (2001), "Learning to be overconfident", Review of Financial Studies, Vol. 14 No. 1, pp. 1-27.

Ghadamyari, M., Mahboobi, Y. and Mehrjardi, M.A. (2017), "Performance evaluation of return, risk and liquidity of firms newly listed in Tehran Stock Exchange", International Journal of Economics and Financial Issues, Vol. 7 No. 1, pp. 249-254.

Ghodrati, H., Fini, S., Azad, N. and Roshan, A. (2014), "Stock market liquidity and firm dividend policy: evidence from Tehran Stock Exchange", Management Science Letters, Vol. 4 No. 8, pp. 1849-1858.

Glaser, M. and Weber, M. (2007), "Overconfidence and trading volume”, The Geneva Risk and Insurance Review, Vol. 32 No. 1, pp. 1-36.

Glosten, L. and Harris, L. (1988), "Estimating the components of the bid/ask spread", Journal of Financial Economics, Vol. 21 No. 1, pp. 123-142.

Goh, B.W., Ng, J. and Yong, K.O. (2009), "The effect of corporate governance on liquidity: voluntary disclosure, analyst coverage and adverse selection as mediating mechanisms", Research Collection School of Accountancy Paper, Singapore Management University, Singapore.

Gopalan, R., Kadan, O. and Pevzner, M. (2012), "Asset liquidity and stock liquidity”, Journal of Financial and Quantitative Analysis, Vol. 47 No. 2, pp. 333-364.

Graham, B. and Zweig, J. (2006), The Intelligent Investor, ISBN: 978-0-06-055566-5, Collins Business Essentials, New York, NY.

Greenwood, R.M. and Sosner, N. (2007), "Trading patterns and excess comovement of stock returns", Financial Analysts Journal, Vol. 63 No. 5, pp. 69-81.

Gresse, C. (2017), "Effects of lit and dark market fragmentation on liquidity", Journal of Financial Markets, Vol. 35, pp. 1-20.

Griffin, C.H. (2010), "Liquidity and dividend policy: international evidence", International Business Research, Vol. 3 No. 3, pp. 3-9.

Harris, L.E. (1994), "Minimum price variations, discrete bid-ask spreads, and quotation sizes", Review of Financial Studies, Vol. 7 No. 1, pp. 149-178.

Harris, M. and Raviv, A. (1993), "Differences of opinion make a horse race”, Review of Financial Studies, Vol. 6 No. 3, pp. 473-506. 
Heflin, F. and Shaw, K.W. (2000), "Blockholder ownership and market liquidity", Journal of Financial and Quantitative Analysis, Vol. 35 No. 4, pp. 621-633.

Hendershott, T.J. and Moulton, P.C. (2011), “Automation, speed, and stock market quality: the NYSE's hybrid”, Journal of Financial Markets, Vol. 14 No. 4, pp. 568-604.

Jegadeesh, N. and Subrahmanyam, A. (1993), "Liquidity effects of the introduction of the S\&P 500 index futures contract on the underlying stocks", The Journal of Business, Vol. 66 No. 2, pp. 171-187.

Jeong, G., Kang, J. and Kwon, K.Y. (2018), "Liquidity skewness premium”, The North American Journal of Economics and Finance, Vol. 46 No. C, pp. 130-150.

Jones, C. (2001), "A century of stock market liquidity and trading cost", working paper, Columbia University, New York, NY, available at: http://dx.doi.org/10.2139/ssrn.313681 (accessed 9 January 2019).

Kalay, A., Wei, L. and Wohl, A. (2002), "Continuous trading or call auctions: revealed preferences of investors at the Tel Aviv stock exchange”, Journal of Finance, Vol. 52 No. 1, pp. 523-542.

Kale, R.J. and Loon, Y.C. (2011), "Product market power and stock market liquidity", Journal of Financial Markets, Vol. 14 No. 2, pp. 376-410.

Karpoff, J.M. and Walkling, R.A. (1990), "Dividend capture in NASDAQ stocks", Journal of Financial Economics, Vol. 28 Nos 1-2, pp. 39-65.

Khan, M.T.I., Tan, S.H. and Chong, L.L. (2016), "The effects of stated preferences for firm characteristics, optimism and overconfidence on trading activities", International Journal of Bank Marketing, Vol. 34 No. 7, pp. 1114-1130.

Khang, K. and King, T.D. (2010), "Short horizon liquidity and trading activity in the U.S. treasury market: do inventory holding costs matter?”, Applied Financial Economics, Vol. 20 No. 14, pp. 1085-1098.

Kim, O. and Verrecchia, R. (1994), "Market liquidity and volume around earnings announcements", Journal of Accounting and Economics, Vol. 17 Nos 1-2, pp. 41-67.

Kyle, A.S. (1985), "Continuous auctions and insider trading”, Econometrica, Vol. 53 No. 6, pp. 1315-1335.

Lee, C., Mucklow, B. and Ready, M. (1993), "Spreads, depths, and the impact of earnings information: an intraday analysis", Review of Financial Studies, Vol. 6 No. 2, pp. 345-374.

Lee, J.H. and Yoon, B. (2017), "Stock market liquidity and dividend policy in Korean corporations", The Journal of Applied Business Research, Vol. 33 No. 4, pp. 731-740.

Lesmond, D., O'Connor, P. and Senbet, L. (2008), “Capital structure and equity liquidity”, Working Paper, Robert H. Smith School Research Paper No. RHS 06-067, Washington, DC, available at: http://dx.doi.org/10.2139/ssrn.1107660

Lipson, M. and Mortal, S. (2009), "Liquidity and capital structure”, Journal of Financial Markets, Vol. 12 No. 4, pp. 611-644.

Lo, A. and Wang, J. (2000), "Trading volume: definitions, data analysis, and implications of portfolio theory", Review of Financial Studies, Vol. 13 No. 2, pp. 257-300.

Lo, A. and Wang, J. (2006), "Trading volume: implications of an intertemporal capital asset pricing model", The Journal of Finance, Vol. 61 No. 6, pp. 2805-2840.

Looi, A. and Gallagher, D.R. (2006), "Trading behaviour and the performance of daily institutional trades”, Accounting and Finance, Vol. 46 No. 1, pp. 125-147.

Lu, J., Hwang, C., Liu, M. and Lin, C. (2016), "An incentive problem of risk balancing in portfolio choices", The Quarterly Review of Economics and Finance, Vol. 61 No. C, pp. 192-200.

Madhavan, A. and Smidt, S. (1991), "A Bayesian model of intraday specialist pricing”, Journal of Financial Economics, Vol. 30 No. 1, pp. 99-134.

Determinants of securities trading activity 
JCMS

3,1

Masoud, N. (2013), "The impact of adopting electronic trading system on performance of the Amman stock exchange", Australian Journal of Business and Management Research, Vol. 3 No. 3, pp. 29-36.

Mcinish, T.H. and Wood, R.A. (1992), "An analysis of intraday patterns in bid/ask spreads for NYSE stocks”, Journal of Finance, Vol. 47 No. 2, pp. 753-764.

Merton, R. (1987), "A simple model of capital market equilibrium with incomplete information", Journal of Finance, Vol. 42 No. 3, pp. 483-510.

Miles, W. (2005), "Do frontier equity markets exhibit common trends and still provide diversification opportunities?”, International Economic Journal, Vol. 19 No. 3, pp. 473-482.

Moel, A. (2001), "The role of American depositary receipts in the development of emerging markets", Economia, Vol. 2 No. 1, pp. 209-257.

Moriyasu, H., Wee, M. and Yu, J. (2018), "The role of algorithmic trading in stock liquidity and commonality in electronic limit order markets", Pacific-Basin Finance Journal, Vol. 49 No. 2, pp. 103-128.

Na'ura, M.A. (2016), “The relationship between firm's stock liquidity and dividends policy”, master's degree dissertation, Faculty of Graduate Studies, Zarqa University, Zarqa, available at: http://zu. edu.jo/UploadFile/PaperFiles/PaperFile_45_10.pdf (accessed 11 December 2018).

$\mathrm{Ng}$, L. and Wu, F. (2006), "Revealed stock preferences of individual investors: evidence from Chinese equity markets”, Pacific-Basin Finance Journal, Vol. 14 No. 2, pp. 175-192.

Pagano, M., Roell, A. and Zechner, J. (2002), "The geography of equity listing: why do companies list abroad?", Journal of Finance, Vol. 57 No. 6, pp. 2651-2694.

Pastor, L. and Stambaugh, R.F. (2003), "Liquidity risk and expected stock returns", Journal of Political Economy, Vol. 111 No. 3, pp. 642-685.

Pham, P.K., Kalev, P.S. and Steen, A.B. (2003), "Underpricing, stock allocation, ownership structure and post-listing liquidity of newly listed firms", Journal of Banking and Finance, Vol. 27 No. 5 , pp. 919-947.

Pinnuck, M. (2004), "Stock preferences and derivative activities of Australian fund managers", Accounting and Finance, Vol. 44 No. 1, pp. 97-120.

Rosu, I. (2009), "A dynamic model of the limit order book”, Review of Financial Studies, Vol. 22 No. 11, pp. 4601-4641.

Santosa, P.W. and Laksana, H.Y. (2011), "Value at risk, market risk and trading activity: CAPM alternative model", Journal of Applied Finance and Banking, Vol. 1 No. 4, pp. 239-268.

Shahani, R. and Sharma, A. (2018), "An empirical investigation into the efficiency parameter through seasonal movements in security prices of the BRICS nations", working paper, University of Delhi, New Delhi.

Stoll, H. (1978), "The pricing of security dealer services: an empirical study of NASDAQ stocks", Journal of Finance, Vol. 33 No. 4, pp. 1153-1172.

Stoll, H. (2000), "Friction", Journal of Finance, Vol. 5 No. 4, pp. 1479-1514.

Sum, V. (2013), "Stock market liquidity and corporate profit growth", unpublished working Paper, Department of Business, Management and Accounting, University of Maryland Eastern Shore, MD, available at: http://dx.doi.org/10.2139/ssrn.2304487 (accessed 19 December 2018).

Tambakis, D.N. (2006), "Can feedback traders rock the markets? A logistic tale of persistence and chaos", working paper, Pembroke College, Cambridge and CERF, Cambridge, MA, available at: www.dspace.cam.ac.uk/handle/1810/225154 (accessed 9 January 2019).

Tinic, S.M. (1972), "The economics of liquidity services", The Quarterly Journal of Economics, Vol. 86 No. 1, pp. 79-93.

World Economic Forum (2017), The Global Competitiveness Report 2017-2018, World Economic Forum, Geneva. 
Yllmaz, M.K., Erdem, O., Eraslan, V. and Arık, E. (2015), "Technology upgrades in emerging equity markets: effects on liquidity and trading activity", Finance Research Letters, Vol. 14 No. C, pp. 87-92.

Zheng, S. and Li, M. (2008), "Underpricing, ownership dispersion, and aftermarket liquidity of IPO stocks”, Journal of Empirical Finance, Vol. 15 No. 3, pp. 436-454.
Determinants of securities trading activity

\section{Further reading}

Chordia, T., Roll, R. and Subrahmanyam, A. (2011), "Recent trends in trading activity and market quality”, Journal of Financial Economics, Vol. 101 No. 2, pp. 243-263.

\section{Corresponding author}

Silvio John Camilleri can be contacted at: silvio.j.camilleri@um.edu.mt 